\title{
PERKAWINAN SIRI (KEDUA DAN SETERUSNYA) PASANGAN PEGAWAI NEGERI SIPIL DI PEMERINTAHAN KABUPATEN SERANG MENURUT PERATURAN PEMERINTAH NOMOR 45 TAHUN 1990, HUKUM ISLAM DAN KOMPILASI HUKUM ISLAM
}

\author{
Djanuardi $\triangle 1$, Eidy Sandra $\triangle^{2}$, Nindya Tien Ramadhanty $\triangle^{3}$ \\ ${ }_{1,2,3}$ Universitas Swadaya Gunung Jati, Cirebon, Indonesia
}

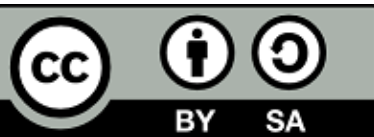

DOI: http://dx.doi.org/10.33603/hermeneutika.v3i2 Diterima: 24 Mei 2020; Direvisi: 19 Juli 2020; Dipublikasikan: Agustus 2020

\begin{abstract}
Abstrak: Perkawinan adalah akad antara seorang pria dengan seorang wanita yang mengikatkan diri dalam hubungan suami istri. Pelaksanaan perkawinan di Indonesia bervariasi, mulai dari perkawinan yang dicatatkan di Kantor Urusan Agama (KUA), perkawinan di bawah umur dan perkawinan siri. Perkawinan siri merupakan perkawinan sah menurut agama, namun tidak memiliki kekuatan secara formal. Faktanya perkawinan siri (kedua dan seterusnya) yang dilakukan oleh pasangan Pegawai Negeri Sipil diatur dalam Peraturan Pemerintah. Permasalahan yang sering terjadi adalah PNS Pria melakukan perkawinan siri (kedua seterusnya) dengan PNS Wanita di pemerintahan Kabupaten Serang. Penelitian ini bertujuan untuk menentukan keabsahan dan akibat hukum dari perkawinan siri (kedua dan seterusnya) yang dilakukan oleh pasangan PNS menurut PP Nomor 45 Tahun 1990 Tentang Izin Perkawinan dan Perceraian PNS dan Kompilasi Hukum Islam. Penelitian ini disusun dengan menggunakan pendekatan yuridis normatif yaitu metode penelitian yang difokuskan untuk mengkaji penerapan kaidah-kaidah atau norma-norma dalam hukum positif kemudian dianalisis secara normatif kualitatif sehingga mendapat suatu fakta. Hasil dari penelitian ini perkawinan siri (kedua dan seterusnya) tidak sah menurut PP Nomor 45 Tahun 1990 Tentang Izin Perkawinan dan Perceraian PNS dan Kompilasi Hukum Islam. Sedangkan perkawinan siri (kedua dan seterusnya) sah menurut Hukum Islam. Akibat hukum dari perkawinan siri ini adalah anak akan dinggap sebagai anak luar kawin yang hanya memiliki hubungan keperdataan dengan ibu dan keluarga ibunya. Akibatnya anak tersebut tidak memiliki hubungan nasab, wali nikah, dan waris dengan ayah biologisnya hanya berhak atas wasiat wajibah.
\end{abstract}

Kata Kunci: Perkawinan, Perkawinan, Pasangan PNS, KUA

\footnotetext{
${ }^{1}$ Djanuardi

Email: djanuardi1111@gmail.com

${ }^{2}$ Eidy Sandra

email : eidysandra@gmail.com

${ }^{3}$ Nindya Tien Ramadhanty

email : nindyatienr@gmail.com
} 


\section{PENDAHULUAN}

Nikah atau zawaj dapat diartikan sebagai kesepakatan antara seorang pria dengan seorang wanita yang mengikatkan diri dalam hubungan suami istri untuk mencapai tujuan hidup dalam melaksanakan ibadat kepada Aallah SWT. Keberadaan nikah sejalan dengan lahirnya manusia di bumi dan merupakan fitrah manusia yang diberikan oleh Allah SWT kepada hambanya ${ }^{4}$. Peraturan mengenai perkawinan di Indonesia tertuang dalam UndangUndang Nomor 1 Tahun 1974 Tentang Perkawinan (selanjutnya disebut UUP). Perkawinan adalah ikatan lahir dan batin antara seorang pria dan seorang wanita sebagai suami istri untuk membentuk keluarga yang bahagia dan kekal berdasarkan Ketuhanan Yang Maha Esa ${ }^{5}$. Asas perkawinan dalam Hukum Indonesia adalah monogami yang tidak mutlak yaitu seorang laki-laki dapat mempunyai istri lebih dari satu apabila ada izin dari istri terdahulu untuk menikah kembali, ${ }^{6}$ namun pada praktiknya banyak terjadi di lingkungan masyarakat yang tidak mengacu kepada UUP, sehingga banyak suami yang melakukan perkawinan kedua dan seterusnya tanpa memperoleh izin dari istri terdahulu.

Dalam kehidupan di masyarakat banyak terjadi perkawinan tanpa adanya pencatatan oleh negara, atau yang dikenal dengan istilah pekawinan siri. Perkawinan siri adalah sah menurut agama, namun tidak memiliki kekuatan hukum secara formal. Beberapa faktor penyebab seseorang tidak mencatatkan perkawinannya di KUA adalah tidak mampu untuk membayar administrasi di KUA tersebut, belum cukup umur untuk melangsungkan perkawinan yang diakui secara hukum oleh negara, dan Pegawai Negeri Sipil yang beristri lebih dari satu orang.

Perkawinan siri (kedua dan seterusnya) yang dilakukan oleh Pasangan

4 Abdul Djamali, Hukum Islam Berdasarkan Ketentuan Kurikulum Konsersium Ilmu Hukum, Bandung: Mandar Maju, 2002, hlm.77.
Pegawai Negeri Sipil di pemerintahan Kabupaten Serang banyak sekali kasus terjadi setiap harinya. Faktor utama yang menyebabkan hal ini terjadi diantaranya ekonomi, perselingkuhan, dan kekerasan. Faktor yang sangat mempengaruhi adalah faktor ekonomi. Faktor ekonomi menjadi penyebab atau alasan seseorang (PNS Pria dan PNS Wanita) melakukan perkawinan siri.

Faktanya perkawinan siri (kedua dan seterusnya) yang dilakukan oleh pasangan Pegawai Negeri Sipil diatur dalam Peraturan Pemerintah. Peraturan Pemerintah Nomor 53 Tahun 2010 tentang Peraturan Disiplin Pegawai Negeri Sipil (yang selanjutnya disebut PP Nomor 53 Tahun 2010). PNS Pria yang akan beristri lebih dari seorang, wajib memperoleh izin dahulu dari Pejabat demikian menurut Pasal 4 ayat (2) PP Nomor 45 Tahun 1990. PNS wanita tidak diizinkan untuk menjadi istri kedua/ketiga/ keempat dari seorang PNS pria demikian menurut Pasal 4 ayat (2) PP Nomor 45 Tahun 1990.

Pada tanggal 30 Agustus 1984 Atmajaya dan Iis Isnaeni melangsungkan perkawinan yang dicatat oleh Pegawai Pencatat Nikah Kantor Urusan Agama Kecamatan Petir Kabupaten Serang sebagaimana tercantum dalam Akta Nikah No.109/I/1984 tertanggal 15 Juni 2009. Atmawijaya dan Iis Isnaeni dikaruniai 2 (dua) orang anak bernama Desi Irma Nilasari dan Denta Nuryuningsih. Atmawijaya seorang Pegawai Negeri Sipil sebagai Kepala Sekolah di SDN Sukamenak UPTD Pendidikan dan Kebudayaan Kecamatan Cikeusal dan Iis Isnaeni seorang Ibu Rumah Tangga.

Atmawijaya telah dua kali menikah dengan perempuan lain selama masih terikat perkawinan dengan Iis Isnaeni. Pertama menikah dengan Nuraini pada tahun 2003, pada saat itu anak dari Atmawijaya dan Iis Isnaeni masih bersekolah, hal ini membuat

\footnotetext{
${ }^{5}$ Subekti, Pokok-pokok Hukum Perdata, Jakarta: PT. Intermasa, 1995, hlm.23.

${ }^{6}$ Ibid hlm. 23 .
} 
tekanan batin kepada Iis Isnaeni dan kedua anaknya. Atmawijaya tidak memberikan nafkah kepada Iis Isnaeni dan kedua anaknya bahkan kedua anaknya mendapatkan perlakuan kekerasan fisik. Lalu setelah Nuraini meninggal dunia, Atmawijaya menikah kembali dengan Bariyah selaku Guru Pegawai Negeri Sipil di SDN Wadas Kubang, Kecamatan Petir, Kabupaten Serang, Banten.

Pada tahun 2018 Iis Isnaeni bersama anaknya Denta Nuryuningsih mengetahui bahwa Atmawijaya menikah kembali dengan perempuan lain tanpa adanya perceraian. Pada saat melakukan perkawinan dengan wanita lain yang bernama Bariyah seorang Pegawai Negeri Sipil sebagai Guru di SDN Wadas Kubang, Kecamatan Petir, Kabupaten Serang, Banten, Atmawijaya telah memalsukan dokumen bahwa seakan-akan ia sudah duda atau cerai dengan istri pertamanya yang bernama Iis Isnaeni. Informasi ini diketahui oleh Iis Isnaeni dari temannya yang merupakan tetangga dari Bariyah.

Iis Isnaeni bersama anaknya Denta Nuryuningsih mengadukan hal ini kepada Bupati Serang sebagai pejabat tertinggi yang ada di lingkungan Kabupaten Serang agar menindaklanjuti kasus tersebut. Hal ini Iis Isnaeni lakukan karena semenjak Atmawijaya menikah dengan Bariyah, kedua anak dan Iis Isnaeni tidak mendapatkan biaya hidup atau mendapatkan bagian dari gaji yang merupakan hak sebagai istri dan anak

\section{METODE PENELITIAN}

Penelitian ini disusun dengan menggunakan medote pendekatan yuridis normatif yaitu metode penelitian yang difokuskan untuk mengkaji penerapan kaidah-kaidah atau norma-norma dalam hukum positif kemudian dianalisis secara normatif kualitatif sehingga mendapatkan fakta yang ada mengenai keabsahan dari perkawinan siri (kedua dan seterusnya) yang dilakukan oleh pasangan Pegawai Negeri Sipil dan akibat hukumnya dikaitkan dengan hukum positif. yang sah. Selain itu Iis Isnaeni mengharapkan Atmajaya dan Bariyah dijatuhkan sanksi atau tindakan hukum yang seadil-adilnya karena keduanya telah melanggar hukum sebagai Pegawai Negeri Sipil.

Pengaduan Iis Isnaeni bersama anaknya Denta Nuryuningsih diterima oleh Badan Kepegawaian dan Sumber Daya Manusia (selanjutnya disingkat BKPSDM) Kabupaten Serang. BKPSDM sebagai badan yang menerbitkan keputusan penjatuhan hukuman disiplin bagi Atmawijaya dan Bariyah sebagai pasangan Pegawai Negeri Sipil yang melakukan perkawinan kedua dan seterusnya. Sebagai Pegawai Negeri Sipil pria yang melakukan perkawinan kedua dan seterusnya harus meminta ijin kepada pejabat yang berwenang dengan alasan tertulis dan Pegawai Negeri Sipil wanita tidak diijinkan menjadi istri kedua, ketiga, dan seterusnya. Pada tanggal 15 Mei 2019 BKPSDM Kabupaten Serang menerbitkan surat permohonan penerbitan keputusan penjatuhan hukuman disiplin kepada Atmawijaya dan Bariyah.

Sepengetahuan Peneliti beum ada penelitian yang membahas menganai Perkawinan Siri (kedua dan seterusnya) Pasangan Pegawai Negeri Sipil di pemerintahan Kabupaten Serang yang Dikaitkan dengan Peraturan Pemerintah Nomor 45 Tahun 1990, Hukum Islam, dan Komplikasi Hukum Islam.

\section{TINJAUAN PUSTAKA}

\section{A. Tinjauan Umum Tentang Perkawinan}

Istilah perkawinan dalam Bahasa Arab adalah nikah. Arti nikah ada dua yaitu arti sebenarnya dan arti kiasan. Arti sebenarnya nikah adalah dham, yang artinya menghimpit, menindih atau berkumpul. Arti kiasannya adalah sama 
dengan wathaa yang artinya bersetubuh ${ }^{7}$. Perkawinan menurut ilmu fikih, disebut dengan istilah nikah, yang mengandung dua arti yaitu, arti menurut bahasa adalah berkumpul atau bersetubuh dan arti menurut hukum adalah akad atau perjanjian dengan lafal tertentu antara seorang laki-laki dengan seorang perempuan untuk hidup bersama sebagai suami istri. ${ }^{8}$

Menurut Sayuthi Thalib, perkawinan adalah perjanjian suci untuk membentuk keluarga antara seorang lakilaki dengan seorang perempuan. ${ }^{9}$ Menurut Sayuti Thalib perkawinan harus dilihat dari tiga segi pandang, yaitu: ${ }^{10}$

a. Perkawinan Dilihat dari Segi Hukum.

Dipandang dari segi hukum, perkawinan itu merupakan suatu perjanjian, dalam Q.S An Nisa ayat 21 yang artinya:

"dan mereka (istri-istrimu) telah mengambil dari kamu perjanjian yang kuat."

Perkawinan adalah perjanjian yang kuat, disebut dengan kata-kata mistaaqan ghalizhan.

Alasan untuk mengatakan perkawinan itu merupakan suatu perjanjian ialah karena adanya:

1) Cara mengadakan ikatan telah diatur terlebih dahulu yaitu dengan akad nikah dan dengan rukun dan syarat tertentu.

2) Cara menguraikan atau memutuskan ikatan perjanjian telah diatur, yaitu dengan prosedur talak, kemungkinan fasakh, syiqaq dan sebagainya.

b. Perkawinan Dilihat dari Segi Sosial.

Dalam masyarakat setiap bangsa, ditemui suatu penilaian yang umum, ialah bahwa orang yang berkeluarga

\footnotetext{
${ }^{7}$ Kamal Muchtar, Asas-asas Hukum Islam Tentang Perkawinan, Jakarta: Bulan Bintang, 1974, hlm. 11

8 Taufiqurrohman Syahuri, Legislasi Hukum Perkawinan di Indonesia (Pra-Kontra Pembentukannya Hingga Putusan Mahkamah Konstitusi), Jakarta: Pranadamedia Group, 2013, hlm 68
}

mempunyai kedudukan yang lebih dihargai dari mereka yang tidak kawin.

c. Perkawinan Dilihat dari Segi Agama. Pandangan perkawinan dari segi agama suatu segi yang sangat penting. Dalam agama, perkawinan itu dianggap suatu lembaga yang suci. Upacara perkawinan adalah upacara yang suci, kedua mempelai dijadikan sebagai suami istri atau saling meminta pasangan hidupnya dengan menggunakan nama Allah, sebagaimana terkandung dalam Q.S An Nisa ayat 1 yang artinya:

"Hai sekalian manusia, bertakwalah kepada Tuhan-mu yang telah menciptakan kamu dari seorang diri, dan dari padanya Allah menciptakan istrinya; dan daripada kedunya Allah memperkembangbiakan laki-laki dan perempuan yang banyak, dan bertakwalah kepada Allah yang dengan (menggunakan) nama-Nya kamu saling meminta satu sama lain, dan (peliharalah) hubungan silaturahmi. Sesungguhnya Allah selalu menjaga dan mengawasi kamu."

Menurut Imam Ghazali, tujuan perkawinan dapat dikembangkan menjadi lima, yaitu: ${ }^{11}$

(1) Mendapatkan dan melangsungkan keturunan.

(2) Memenuhi hajat manusia (menyalurkan syahwatnya) untuk menumpahkan kasih sayang.

(3) Memelihara manusia dari kerusakan.

(4) Menumbuhkan kesungguhan untuk memperoleh harta kekayaan yang halal.

(5) Membangun rumah tangga untuk masyarakat yang tenteram atas dasar cinta dan kasih sayang.

Terdapat asas-asas perkawinan

9 Sayuti Thalib, Hukum Kekeluargaan Indonesia, Bogor: Ghalia Indonesia, 2009, hlm. 47

${ }^{10}$ Ibid

${ }^{11}$ Abdul Rahman Ghozali, Fiqh Munakahat, Jakarta: Prenada Media Grup, 2003.hlm. 46 
p-ISSN 2337-6368 | e-ISSN 2615-4439

http://jurnal.unswagati.ac.id/index.php/HERMENEUTIKA

menurut Kompilasi Hukum Islam, diantaranya sebagai berikut:
a. Asas Persetujuan.
b. Asas kebebasan.
c. Asas kemitraan suami-istri.
d. Asas untuk selama-lamanya.
e. Asas kemaslahatan hidup.
f. Asas kepastian hukum.

\section{B. Tinjuan Tentang Perkawinan Siri Menurut Hukum Islam}

Mengenai perkawinan siri, Imam Abu Hanifah, Imam Malik dan Imam Syafi'i sepakat bahwa tidak boleh melakukan perkawinan secara rahasia (siri). Mereka berbeda pendapat jika mendatangkan saksi 2 (dua) orang, lalu keduanya diwasiatkan untuk merahasiakannya, apakah perkawinan tersebut termasuk perkawinan siri atau bukan, Imam Malik mengatakan itu adalah ikatan nikah secara rahasia dan harus dibatalkan, sedangkan Imam Abu Hanifah mengatakan itu bukan termasuk nikah secara rahasia. ${ }^{12}$

Perbedaan pendapat yang terjadi di antara mereka terletak pada kesaksian, apakah kesaksian dalam hal ini merupakan hukum syar'i atau maksud dari kesaksian tersebut adalah menutup jalan perselisihan atau pengingkaran. Ulama yang menyatakan bahwa itu adalah hukum syar'i mengatakan bahwa kesaksian adalah salah satu syarat sah, sedangkan ulama yang berpendapat bahwa persaksian itu hanya untuk pembuktian mengatakan bahwa kesaksian termasuk syarat kesempurnaan. ${ }^{13}$

Adapun dalam perkembangannya, perkawinan siri yang terjadi di Indonesia saat ini merupakan perkawinan yang memenuhi syarat-syarat dan rukun-rukun perkawinan sehingga dipandang sah menurut hukum Islam, namun apabila perkawinan dilaksanakan tanpa adanya wali dan saksi maka perkawinan tersebut tidak sah. ${ }^{14}$ Perkawinan siri juga dapat diartikan

${ }^{12}$ Ibnu Rusyd, Bidayah Al-Mujtahid, Jakarta: Pustaka Azzam. 2011, hlm. 31

${ }^{13}$ Ibid, hlm. 32 sebagai perkawinan yang dilakukan secara sembunyi-sembunyi, ada yang dicatat tapi disembunyikan dari masyarakat dan ada pula yang tidak dicatatkan pada Petugas Pencatat Nikah (PPN) dan tidak terdaftar di Kantor Urusan Agama (KUA). ${ }^{15}$

Perkawinan siri merupakan nikah yang masih dirahasiakan, artinya belum diberitahukan kepada umum. Biasanya dilakukan ijab dalam kalangan terbatas, di muka Kiai atau tokoh agama, tanpa kehadiran petugas KUA, dan tentu saja tidak memiliki surat nikah yang resmi. ${ }^{16}$

C. Tinjauan Tentang Perkawinan Menurut Peraturan Pemerintah Nomor 45 Tahun 1990 Tnteng Izin Perkawinan dan Perceraian Pegawai Negeri Sipil

Pasal 4 PP Nomor 45 Tahun 1990

Tentang Izin Perkawinan dan Perceraian bagi Pegawai Negeri Sipil (selanjutnya disebut PP Nomor 45 Tahun 1990) menyebutkan bahwa Pegawai Negeri Sipil (selanjutnya disebut PNS) pria yang akan beristri lebih dari seorang wajib memperoleh izin lebih dahulu dari Pejabat, permintaan izin diajukan secara tertulis dengan mencantunkan alasan yang lengkap mendasari permintaan izin untuk beristri lebih dari seorang, sedangkan PNS wanita tidak diizinkan menjadi istri kedua/ketiga/keempat.

Pasal 3 ayat (1) PP Nomor 45 Tahun 1990, berlaku bagi setiap PNS yang akan melakukan perceraian, yaitu bagi PNS yang mengajukan gugatan perceraian (penggugat) wajib memperoleh izin lebih dahulu dari Pejabat, sedangkan bagi PNS yang menerima gugatan perceraian (tergugat) wajib memperoleh surat keterangan lebih dahulu dari Pejabat sebelum melakukan perceraian. Selanjutnya penjelasan Pasal 3 ayat (2) PP Nomor 45 Tahun 1990 menyatakan permintaan izin perceraian diajukan oleh penggugat kepada Pejabat secara tertulis

14 Fatihuddin Abul Yasin, Risalah Hukum Nikah, Surabaya: Terbit Terang, 2006, hlm. 65

${ }^{15}$ Mardani, Op.Cit, hlm. 17

${ }^{16}$ Ibid 
melalui saluran hierarki sedangkan tergugat wajib memberitahukan adanya gugatan perceraian dari suami/istri secara tertulis melalui saluran hierarki dalam jangka waktu selambat-lambatnya enam hari kerja setelah menerima gugatan perceraian.

Berkenaan dengan jangka waktu kewajiban Atasan memberikan pertimbangan dan meneruskan kepada Pejabat, mengacu Pasal 5 ayat (2) PP Nomor 45 Tahun 1990 setiap Atasan yang menerima permintaan izin dari PNS dalam lingkungannya, baik untuk perceraian dan atau untuk beristri lebih dari seorang, wajib memberikan pertimbangan dan meneruskannya kepada Pejabat melalui saluran hierarki dalam jangka waktu selambat-lambatnya tiga bulan terhitung mulai tanggal ia menerima permintaan izin.

\section{PEMBAHASAN}

A. Keabsahan dari perkawinan siri (kedua dan seterusnya) yang dilakukan oleh pasangan Pegawai Negeri Sipil di Pemerintahan Kabupaten Serang menurut Peraturan Pemerintah Nomor 45 Tahun 1990 Tentang Izin Perkawinan dan Perceraian bagi Pegawai Negeri Sipil, Hukum Islam, dan Kompilasi Hukum Islam

Perkawinan siri artinya perkawinan yang dilangsukan secara agama belum luzum kebasahannya (belum diakui keberadaannya) di hadapan negara selama belum dicatatkan. Sebagai solusi hukum terhadap perkawinan yang telah dilakukan tetapi belum dicatatkan maka diberikan kesempatan untuk melakukan permohonan pengesahan nikah (itsbat nikah), sehingga selama perkawinan siri tersebut dapat dibuktikan di persidangan pengadilan telah dilangsungkan sesuai dengan aturan agama dapat ditetapkan keabshannya. ${ }^{17}$

PNS pria yang ingin beristri lebih dari satu diatur dalam aturan khusus dalam
PP Nomor 45 Tahun 1990, wajib memperolah izin terlebih dahulu dari Pejabat demikian menurut Pasal 4 ayat (1) PP Nomor 45 Tahun 1990, hal ini dilakukan karena perkawinan merupakan suatu lembaga yang suci. Demikian pula kehidupan rumah tangga seorang PNS diharapkan dapat berjalan secara bahagia, tentram, tertib penuh kedamaian.

PNS Pria yang akan beristri lebih dari seorang, wajib memperoleh izin dahulu dari Pejabat demikian menurut Pasal 4 ayat (1) PP Nomor 45 Tahun 1990, selanjutnya ayat (3) menyebutkan bahwa permintaan izin sebagaimana dimaksud ayat (1) diajukan secara tertulis, dan ayat (4) menyebutkan bahwa dalam surat permintaan izin sebagaimana dimaksud dalam ayat (3), harus dicantumkan alasan yang lengkap mendasari permintaan izin untuk beristeri lebih dari seorang.

Setiap atasan yang menerima permintaan izin dari PNS dalam lingkungannya, untuk beristeri lebih dari seorang, wajib memberikan pertimbangan dan meneruskannya kepada Pejabat melalui saluran hierarki dalam jangka waktu selambat-lambatnya tiga bulan terhitung mulai tanggal ia menerima permintaan izin dimaksud demikian menurut Pasal 5 ayat (2) PP Nomor 45 Tahun 1990. Setiap atasan yang menerima permintaan izin tersebut memberikan pertimbangannya secara tertulis kepada Pejabat, pertimbangan itu harus memuat hal-hal yang dapat digunakan oleh Pejabat dalam mengambil keputusan, apakah permintaan izin itu mempunyai dasar yang kuat. Sebagai bahan untuk membuat pertimbangan, atasan yang bersangkutan dapat meminta keterangan dari suami/istri yang bersangkutan atau dari pihak lain yang dipandang dapat memberikan keterangan yang meyakinkan demikian menurut Penjelasan Pasal 5 ayat (2).

Pejabat yang menerima permintaan

17 Siti Ummu Adillah, "Implikasi Hukum Dari Perkawinan Siri Terhadap Perempuan dan Anak", Jurnal Palasren Volume 7, Nomor 1, 2014 
izin untuk beristri lebih dari seorang sebagaimana dimaksud Pasal 4 ayat (1) wajib memperhatikan dengan seksama alasanalasan yang dikemukakan dalam surat permintaan izin dan pertimbangan dari atasan PNS yang bersangkutan demikian menurut Pasal 9 ayat (1) PP Nomor 45 Tahun 1990.

PNS dilarang hidup bersama dengan wanita yang bukan istrinya atau dengan pria yang bukan suaminya sebagai suami istri tanpa ikatan perkawinan yang sah demikian menurut Pasal 14 PP Nomor 45 Tahun 1990, yang dimaksud hidup bersama adalah melakukan hubungan sebagai suami istri di luar perkawinan yang sah seolah-olah merupakan suatu rumah tangga.

Izin untuk beristri lebih dari seorang tidak diberikan oleh Pejabat apabila bertentangan dengan ajaran atau peraturan agama yang dianut oleh PNS yang bersangkutan, bertentangan dengan peraturan perundang-undangan yang berlaku, alasan yang dikemukakan bertentangan dengan akal sehat, dan ada kemungkinan mengganggu pelaksanaan tugas kedinasan. ${ }^{18}$

PNS wanita tidak diizinkan untuk menjadi istri kedua/ketiga/ keempat dari seorang PNS pria demikian menurut Pasal 4 ayat (2) PP Nomor 45 Tahun 1990. PNS wanita disini meliputi PNS wanita yang belum pernah menikah dan PNS wanita yang sudah pernah menikah, dengan kata lain semua PNS wanita tidak diizinkan menjadi istri kedua/ketiga/keempat. Hal ini diatur karena untuk memenuhi tujuan dari perkawinan yang diatur dalam UUP. Tujuan perkawinan dalam UUP yaitu membentuk keluarga (rumah tangga) yang bahagia dan kekal berdasarkan ketuhanan Yang Maha Esa. ${ }^{15}$ Apabila PNS wanita diizinkan menjadi istri kedua/ketiga/keempat, akan menjadikan dirinya sebagai wanita lain dalam perkawinan/rumah tangga yang telah terbina sebelumnya. Apabila dilanggar

18 Soegeng Prijodarminto, Duri dan Mutiara dalam Kehidupan Perkawinan PNS, Jakarta: PT Pradnya Paramita, 1992, hlm. 42 maka PNS wanita tersebut diberhentikan dengan hormat tidak atas permintaan sendiri demikian berdasarkan Pasal 15 ayat (2).

PNS pria yang melanggar salah satu atau lebih kewajiban/ketentuan Pasal 4 ayat (1), tidak melaporkan perkawinannya yang kedua/ketiga/keempat dalam waktu selambat-lambatnya satu tahun terhitung sejak perkawinan tersebut dilangsungkan, maka PNS tersebut dijatuhi salah satu hukuman disiplin berat demikian menurut PP Nomor 53 Tahun 2010 dan ayat (2) yang menyebutkan bahwa PNS wanita yang melanggar ketentuan Pasal 4 ayat (2) tersebut, dijatuhi hukuman disiplin pemberhentian tidak hormat sebagai PNS.

Faktor-faktor yang menyebabkan terjadinya perkawinan siri ini beragam antara lain untuk menghindari perbuatan zina, tidak mampu membayar biaya proses pencatatan perkawinan, agar dapat melakukan poligami karena calon mempelai pria tidak mendapat izin dari istrinya sebagaimana diamanatkan oleh undang-undang, salah satu pihak masih terikat perjanjian dengan tempatnya bekerja tentang larangan menikah sampai batas waktu yang telah ditentukan, anggapan banyak orang terkait pencatatan perkawinan bukan merupakan perintah agama dan yang terakhir faktor ekonomi, serta faktor yang paling dominan adalah faktor ekonomi yang menyebabkan seseorang melakukan perkawinan siri. ${ }^{19}$

Suami yang hendak beristri lebih dari satu orang harus mendapat izin dari Pengadilan Agama demikian disebutkan dalam Pasal 56 ayat (1) KHI, apabila tidak ada izin dari Pengadilan Agama, maka tidak mempunyai kekuatan hukum. Hal ini dilakukan agar Pengadilan Agama mengetahui bahwa adanya perkawinan kedua/ketiga/seterusnya. Pasal 57 KHI menyebutkan bahwa Pengadilan Agama hanya memberikan izin kepada seorang

19 Abdullah, Abdul Ghani, Pengantar Kompilasi Hukum Islam, Jakarta: Gema Insani Press, 1994, hlm. 105 
suami yang akan beristri lebih dari seorang apabila istri tidak dapat menjalankan kewajiban sebagai istri, istri mendapat cacat badan atau penyakit yang tidak dapat disembuhkan dan istri tidak dapat melahirkan keturunan. Pelaksanaan perkawinan siri harus memenuhi syarat utama dan syarat lain, agar Pengadilan Agama memberikan izin kepada suami yang ingin beristri lebih dari satu orang.

Apabila mengacu pada aturanaturan di atas, maka perkawinan siri yang dilakukan oleh pasangan PNS tidak sah menurut KHI karena suami atau PNS pria tidak meminta izin pada Pengadilan Agama (tidak sesuai dengan Pasal 56 ayat (1) KHI) serta tidak ada persetujuan istri (tidak sesuai dengan Pasal 58 ayat (1) KHI). Selain itu, suami atau PNS pria harus memenuhi syarat-syarat tertentu untuk beristri lebih dari satu orang yaitu apabila istri tidak dapat menjalankan kewajiban sebagai istri, istri mendapat cacat badan atau penyakit yang tidak dapat disembuhkan dan istri tidak dapat melahirkan keturunan demikian menurut Pasal 57 KHI.

B. Akibat hukum dari perkawinan siri (kedua dan seterusnya) yang dilakukan oleh pasangan Pegawai Negeri Sipil di Pemerintahan Kabupaten Serang menurut Peraturan Pemerintah Nomor 45 Tahun 1990 Tentang Izin Perkawinan dan Perceraian bagi Pegawai Negeri Sipil dan Kompilasi Hukum Islam

Perkawinan yang sah hanya dapat dibuktikan dengan buku nikah, artinya perkawinan yang tidak dapat dibuktikan dengan buku nikah, maka perkawinan tersebut tidak mempunyai akibat hukum. Perkawinan tidak dicatatkan mengakibatkan banyak anak yang tidak tercatat di catatan sipil. Imbasnya anak tidak memiliki identitas karena UU Nomor 23 Tahun 2006 mensyaratkan pengajuan akta kelahiran harus disertai dokumen perkawinan dari

20 Ali Uraidy, "Perkawinan Sirri dan Akibat Hukumnya Ditinjau Dari Undang-Undang No. 1 negara. Padahal tanpa akta kelahiran, anak akan keseulitan mendapatkan Kartu Tanda Penduduk atau selanjutnya disebut KTP, paspor, mendaftar sekolah dan untuk mendapatkan hak-hak lainnya.

Nikah siri yang terjadi di Indonesia ini tetap dipandang sah dalam perspektif agama apabila telah terpenuhinya rukun dan syaratnya, tetapi akad ini dapat menimbulkan dampak atau akibat hukum yang merugikan pada sumai dan terutama istri dan anakanaknya. Ali Uraidy mengungkapkan akibatakibat hukum dari perkawinan siri diantaranya: ${ }^{20}$

1. Tidak adanya kekuatan hukum yang tetap terhadap legalitas perkawinan tersebut;

2. Nikah siri yang dilakukan cenderung tidak dapat dibuktikan secara hukum dan suami istri yang melaksanakan akad nikah siri tidak dapat membuktikan bahwa keduanya merupakan pasangan yang legal dimata hukum karena usia yang dimiliki saksi terbatas serta suami istri tersebut bisa saja berpindah-pindah tempat tinggal;

3. Kepentingan-kepentingan suami istri lainnya dalam menjalani kehidupan berumah tangga tidak dapat dilindungi;

4. Karena tidak ada bukti perkawinan tersebut, seperti terkait dengan pembuatan Kartu Tnda Penduduk (KTP), Kartu Keluarga (KK), Pasport, Akta Kelahiran Anak. Semua itu karena tidak adanya bukti perkawinan berupa Akta Nikah/Buku Nikah;

5. Nikah siri cenderung membuat salah satu pasangan, khususnya suami lebih leluasa untuk meninggalkan kewjibannya;

6. Nikah siri dapat berakibat mempengaruhi kemaslahatan agama, artinya ajaran agama cenderung dipraktekan secara kacau. Dapat digambarkan bahwa apabila suatu akad nikah tidak dicatat secara resmi di hadapan pejabat yang berwenang yakni

Tahun 1974", Jurnal Ilmiah FENOMENA, Volume X, Nomor 2, 2015 
Pegawai Pencatat Nikah, maka akad nikah seperti ini tidak dapat dikontrol. Akhirnya dapat membuka peluang pada suami untuk melakukan akad nikah kembali dengan perempuan lain tanpa terlebih dahulu mendapatkan persetujuan secra resmi dari istri pertama melalui proses persidangan. ${ }^{21}$

7. Nikah siri dapat berakibat mempengaruhi kemaslahatan psikologis anak dan istri, artinya syarat untuk membuat akte kelahiran anak adalah buku nikah dari kedua orang tuanya. Apabila tidak memiliki buku nikah maka akte kelahiran tidak bisa dibuat karena akte kelahiran merupakan bukti hukum untuk menyatakan bahwa seorang anak tersebut adalah anak sah pasangan suami istri;

8. Nikah siri dapat berakibat mempengaruhi kemaslahatan keturunan, dengan tidak tercatatnya akad nikah maka anak yang dilahirkan pun tidak memiliki identitas yang jelas sehingga cenderung dianggap sebagai anak hasil hubungan yang tidak sah;

9. Nikah siri dapat berakibat mempengaruhi kemaslahatan harta, karena tidak jelasnya identitas perkawinan dan perkawinan pun tidak dapat dibuktikan melalui buku nikah maka identitas anak yang dilahirkan juga tidak jelas, sehingga ketika orang tuanya meninggal, anak akan kesulitan untuk mendapatkan harta waris dari orang tuanya, termasuk juga istri dari perkawinan siri ini akan kesulitan untuk menyatakan dirinya sebagai ahli waris yang sah. ${ }^{22}$

PP Nomor 45 Tahun 1990 tidak mengatur terkait perlindungan hukum bagi istri dari perkawinan siri dan anak yang lahir dari perkawinan siri yaitu tidak

21 Irfan Islami, "Perkawinan Di Bawah Tangan (Kawin Siri) Dan Akibat Hukumnya", Jurnal Hukum Volume 8, Nomor 1, 2018

22 Putri Rahmalia, Penolakan Penetapan Isbat Nikah Terhadap Perkawinan Siri (Studi Putusan memiliki hak terkait pembagian harta bersama, pewarisan, perwalian.

Pasal 99 KHI menyatakan anak yang sah adalah anak yang dilahirkan dalam atau sebagai akibat perkawinan yang sah dan hasil perbuatan suami istri yang sah di luar rahim dan dilahirkan oleh istri tersebut. Pasal 100 KHI menyebutkan bahwa anak yang dilahirkan di luar perkawinan hanya mempunyai hubungan nasab dengan ibunya dan keluarga ibunya, sehingga anak tidak mempunyai hubungan nasab dengan ayahnya, wali, dan waris. Anak tidak mempunyai hubungan hukum dengan bapaknya. Hal ini akan berdampak pada jiwa anak karena dianggap anak luar kawin.

Pasal 171 huruf c KHI menyatakan bahwa ahli waris adalah orang yang pada saat meninggal dunia mempunyai hubungan darah atau hubungan perkawinan dengan pewaris, beragama Islam dan tidak terhalang karena hukum untuk menjadi ahli waris. Oleh karena anak luar nikah tidak memiliki hubungan nasab dengan ayahnya, maka anak tersebut tidak tergolong dalam ahli waris.

Setelah keluarnya Putusan Mahkamah Konstitusi Nomor 46/PUUVIII/2010 terhadap persoalan anak luar kawin yang pada intinya mengubah rumusan Pasal 43 ayat (1) UUP yang dinilai bertentangan dengan UUD 1945 sehingga pasal tersebut harus dibaca: ${ }^{23}$

"Anak yang dilahirkan di luar perkawinan mempunyai hubungan perdata dengan ibunya dan keluarga ibunya serta dengan laki-laki sebagai ayahnya yang dapat dibuktikan berdasarkan ilmu pengetahuan dan teknologi dan/atau alat bukti lain menurut hukum mempunyai hubungan darah, termasuk hubungan perdata dengan keluarga ayahnya."

Berdasarkan uraian tersebut, hubungan anak dengan seorang laki-laki

1155/Pdt.P/2013/Pajp), Skripsi Fakultas Hukum Universitas YARSI, 2017

23 Zahry Hamid, Pokok-Pokok Hukum Perkawinan Islam dan UU Perkawinan di Indonesia, Yogyakarta: Bina Cipta, 2014, hlm. 78

148 Hermeneutika : Jurnal Ilmu Hukum

Vol. 4, No. 2, August 2020 
sebagai bapak tidak semata-mata karena adanya ikatan perkawinan, akan tetapi juga didasarkan pada pembuktian adanya hubungan darah antara anak dengan lakilaki tersebut sebagai bapak. Dengan demikian, terlepas dari soal prosedur/administrasi perkawinannya, anak yang dilahirkan harus mendapatkan perlindungan hukum. Jika tidak demikian, maka yang dirugikan adalah anak yang dilahirkan di luar perkawinan, padahal anak tersebut tidak berdosa karena kelahirannya di luar kehendaknya. Hukum harus memberi perlindungan dan kepastian hukum yang adil terhadap status seorang anak yang dilahirkan dan hak-hak yang ada padanya, termasuk terhadap anak yang dilahirkan meskipun keabsahan perkawinanya masih dipersengketakan. ${ }^{24}$ Fatwa dari MUI Nomor 11 Tahun 2012 tanggal 10 Maret 2012 yang menyatakan bahwa anak luar kawin tersebut hanya berhak atas wasiat wajibah, sehingga walaupun anak luar kawin dapat diakui sebagai anak sah setelah adanya putusan MK Nomor 46/PUU-VIII/2012 namun bagi

\section{KESIMPULAN}

Berdasarkan uraian yang telah dikemukakan pada bab-bab sebelumnya, maka Penulis menarik kesimpulan sebagai berikut:

1. Perkawinan siri (kedua dan seterusnya) yang dilakukan oleh pasangan PNS di Pemerintahan Kabupaten Serang menurut PP Nomor 45 Tahun 1990 Tentang Izin Perkawinan dan Perceraian PNS adalah tidak sah karena PNS pria yang akan beristri lebih dari seorang wajib memperoleh izin dari Pejabat demikian berdasarkan Pasal 4 ayat (1) PP Nomor 45 Tahun 1990 dan PNS wanita tidak diizinkan menjadi istri kedua/ketiga/keempat demikian berdasarkan Pasal 4 ayat (2) PP Nomor

\footnotetext{
${ }^{24}$ Ibid

${ }^{25}$ Ali, "Ini Dia Fatwa MUI Anak Hasil Zina",
}

orang Islam berlaku Fatwa MUI Nomor 11 Tahun 2012 yang menyatakan anak luar kawin tersebut tidak memiliki hubungan nasab, wali nikah dan waris dengan ayah biologisnya. ${ }^{25}$

Berdasarkan uraian di atas, maka akibat hukum perkawinan siri (kedua dan seterusnya) yang dilakukan oleh pasangan PNS di Pemerintahan Kabupaten Serang menurut KHI terhadap anak adalah anak yang lahir dari perkawinan siri merupakan anak luar kawin yang hanya mempunyai hubungan nasab dengan ibunya dan keluarga ibunya (karena perkawinan ibu dan bapaknya merupakan perkawinan yang tidak dicatat oleh PPN, sehingga perkawinan tersebut tidak memiliki kekuatan hukum), baik ibu maupun anak tidak mendapatkan hak-hak sebagai istri dan anak, anak tidak mempunyai hubungan nasab dengan ayahnya, wali, dan waris, namun bagi orang Islam berlaku Fatwa MUI Nomor 11 Tahun 2012 yang menyatakan anak luar kawin tidak memiliki hubungan nasab, wali nikah dan waris dengan ayah biologisnya hanya berhak atas wasiat wajibah.

45 Tahun 1990, menurut hukum islam adalah sah karena memenuhi syarat dan rukun serta tidak melanggar larangan perkawinan, sedangkan menurut KHI adalah tidak sah karena suami harus meminta izin pada Pengadilan Agama demikian berdasarkan Pasal 56 ayat (1) KHI dan harus memperoleh persetujuan istri demikian berdasarkan Pasal 58 ayat (1) KHI.

2. PP Nomor 45 Tahun 1990 Tentang Izin Perkawinan dan Perceraian bagi PNS tidak mengatur akibat hukum yang ditimbulkan dari perkawinan siri (kedua dan seterusnya) yang dilakukan oleh pasangan PNS di Pemerintahan Kabupaten Serang serta adanya sanksi hukum yang tegas berupa penurunan atau pemberhentian dari jabatan,

e9f2fa/inidiafatwamuitentanganak-hasil-zina, [31/10/19]

https://www.hukumonline.com/berita/baca/lt4f632f5 
sedangkan menurut KHI anak yang lahir di luar kawin hanya mempunyai hubungan nasab dengan ibunya demikian berdasarkan Pasal $100 \mathrm{KHI}$ walaupun anak luar kawin dapat diakui sebagai anak sah setelah adanya putusan MK Nomor 46/PUUVIII/2012 namun bagi orang Islam berlaku Fatwa MUI Nomor 11 Tahun 2012 yang menyatakan anak luar kawin tersebut tidak memiliki hubungan nasab, wali nikah dan waris dengan ayah biologisnya hanya berhak atas wasiat wajibah.

\section{DAFTAR PUSTAKA}

\section{Buku:}

Abdul Djamali, Hukum Islam Berdasarkan Ketentuan Kurikulum Konsersium Ilmu Hukum, Bandung: Mandar Maju, 2002

Abdullah, Abdul Ghani, Pengantar Kompilasi Hukum Islam, Jakarta: Gema Insani Press, 1994

Djoko Prakoso, I Ketut Murtika, Asas-asas Hukum Perkawinan di Indonesia, Jakarta: PT. Bina Aksara, 1987

Subekti, Pokok-pokok Hukum Perdata, Jakarta: PT. Intermasa, 1995

Kamal Muchtar, Asas-asas Hukum Islam Tentang Perkawinan, Jakarta: Bulan Bintang, 1974

Taufiqurrohman Syahuri, Legislasi Hukum Perkawinan di Indonesia (Pra-Kontra Pembentukannya Hingga Putusan Mahkamah Konstitusi), Jakarta: Pranadamedia Group, 2013

Sayuti Thalib, Hukum Kekeluargaan Indonesia, Bogor: Ghalia Indonesia, 2009 Abdul Rahman Ghozali, Fiqh Munakahat, Jakarta: Prenada Media Grup, 2003 Ibnu Rusyd, Bidayah AlMujtahid, Jakarta: Pustaka Azzam. 2011

Zahry Hamid, Pokok-Pokok Hukum Perkawinan Islam dan UU Perkawinan di Indonesia, Yogyakarta: Bina Cipta, 2014

\section{Artikel/Jurnal:}

Ali Uraidy, "Perkawinan Sirri dan Akibat Hukumnya Ditinjau Dari UndangUndang

No. 1 Tahun 1974", Jurnal Ilmiah FENOMENA, Volume X, Nomor 2, 2015

Siti Ummu Adillah, "Implikasi Hukum Dari Perkawinan Siri Terhadap Perempuan

dan Anak", Jurnal Palasren Volume 7, Nomor 1, 2014

Irfan Islami, "Perkawinan Di Bawah Tangan (Kawin Siri) Dan Akibat Hukumnya", Jurnal Hukum Volume 8, Nomor 1, 2018

Putri Rahmalia, Penolakan Penetapan Isbat Nikah Terhadap Perkawinan Siri (Studi

Putusan 1155/Pdt.P/2013/Pajp), Skripsi Fakultas Hukum Universitas YARSI, 2017

\section{Peraturan Perundang-undangan:}

Undang-Undang Perkawinan Nomor 1 Tahun 1974 Tentang Perkawinan Undang-Undang Nomor 8 Tahun 1974 Tentang Pokok-Pokok Kepegawaian

Undang-Undang Nomor 43 Tahun 1999 Tentang Pokok-Pokok Kepegawaian Perubahan Atas Undang-Undang Nomor 88 Tahun 1974

Undang-Undang Nomor 5 Tahun 2014 Tentang Aparatur Sipil Negara

Peraturan Pemerintah Nomor 45 Tahun 1990 Tentang Izin Perkawinan dan Perceraian bagi Pegawai Negeri Sipil

Peraturan Pemerintah Nomor 53 Tahun 2010 Tentang Peraturan Disiplin Pegawai Negeri Sipil Instruksi Presiden Nomor 1 Tahun 1991 Tentang Kompilasi Hukum Islam

\section{Sumber Lain:}

Ali, "Ini Dia Fatwa MUI Anak Hasil Zina", $<$ https://www.hukumonline.com/berit a/baca/lt4f632f5e9f2fa/inidiafatwamui tentanganak-hasil-zina $>$ 